\title{
3-Oxo-5-Alpha-Steroid 4-Dehydrogenase 1
}

National Cancer Institute

\section{Source}

National Cancer Institute. 3-Oxo-5-Alpha-Steroid 4-Dehydrogenase 1. NCI Thesaurus. Code C105160.

3-oxo-5-alpha-steroid 4-dehydrogenase 1 ( $259 \mathrm{aa}, \sim 29 \mathrm{kDa}$ ) is encoded by the human SRD5A1 gene. This protein is involved in sexual differentiation and androgen physiology. 